\title{
Characterization of cereal bars enriched with dietary fiber and omega 3
}

\section{Caracterizacao de barras de cereal enriquecidas com fibra dietética e omega 3}

\begin{abstract}
The aim of the present work was to characterize cereal bars with high levels of fiber and $w-3$ using functional ingredients. Formulations were developed containing 0\%, 5\%, 10\% and $20 \%$ of linseed. Proximate chemical, w-linolenic and linoleic acids and acceptability analyses were carried out. The carbohydrate concentrations of the cereal bars with linseed were lower than those of the control $(p<0.004)$; while the protein content did not differ among the formulations ( $p>0.05$ ). The bar containing $20 \%$ of linseed presented higher lipid content $(p<0.001)$. The formulations with $5 \%$ and $10 \%$ of linseed were considered sources of dietary fiber, while the formulation with $20 \%$ was considered a good source. Regarding -3, the formulations containing linseed were classified as excellent sources. The calorie value of the cereal bars was around $100 \mathrm{kcal} /$ portion. The formulations containing linseed presented higher acceptability, and that with $20 \%$ of linseed was found to be the formulation with the best chemical and sensory characteristics. Therefore, the addition of linseed in cereal bars is a good option to develop a functional product, which may contribute to a healthy diet and to the reduction of several non-communicable diseases.

Key words: New food products; linseed; functional properties; consumer acceptability.
\end{abstract}

\section{INTRODUCTION}

Over the past few decades there has been growing interest in products that, besides the basic nourishing function, promote health benefits. This growing search puts certain foods and ingredients in the preference list of an increasing number of consumers, including the linseed (Linum usitatissimum) (1-3).

Linseed is an oleaginous that has been used in the human diet for thousands of years, and at present. It has been widely spread due to its functional allegations (3-5). In agreement with Faintuch et al. (6), linseed flour presents anti-inflammatory action, reducing cholesterol and triglycerides levels in obese patients.

The $\alpha$-linolenic acid $(\omega-3)$ concentration in linseed is more than $50 \%$ its lipid content (7), characterizing this seed as the high vegetable source of this fatty acid. Studies point to the beneficial effects of $\omega-3$ in child growth and development, a reduction of risk factors for cardiovascular diseases, dyslipidemia, central nervous system functioning and in inflammatory disorders $(7,8)$.

Linseed presents proteins with an amino acid composition that is similar to soy, and is considered a seed with good
Nathália Silva de Paula (1)

Dorina Isabel Gomes Natal (1)

Hiani Aparecida Ferreira (2)

Maria Inês de Souza Dantas (1)

Sônia Machado Rocha Ribeiro (1)

Hércia Stampini Duarte Martino (1)

(1) Department of Nutrition and Health, University Campus, Federal University of Viçosa (UFV). MG, Brazil. (2) Department of Food Technology, University Campus, Federal University of Viçosa (UFV). MG, Brazil.

Correspondent author: Professor Hércia Stampini Duarte Martino Departamento de Nutrição e Saúde (DNS) Campus Universitário S/N Universidade Federal de Viçosa (UFV) Viçosa, MG, 36570-000 Brazil Tel: 55 (031) 3899-2545 Fax: 55 (031) 3899-2541 E-mail: hercia@ufv.br

Este trabajo fue recibido el 29 de Enero de 2013 y aceptado para ser publicado el 20 de Julio de 2013. protein quality among vegetable origin products (9). This oleaginous is also rich in dietary fiber $(10,11)$, potentiating physical weight reduction, the prevention of diabetes and cardiovascular diseases $(12,13)$, besides preventing constipation, diverticulitis, hemorrhoids and colon cancer (13, 14). In addition, it presents phytoestrogens and phenolic compounds, especially lignans, associated with antioxidant properties, a reduction of breast and prostate cancer risk and diabetes prevention (3).

In view of the low linseed intake in the Brazilian diet, the development of cereal bars enriched with this seed is a good alternative to increase its consumption and promote a healthier diet. In this context, cereal bars stand out, as they present great market popularity due to their handiness, taste and nutritional value, being a good alternative for those who look for healthy and low calorie food in snacks or to complement meals $(15,16)$.

Considering that there aren't researches about cereal bars with added linseed, the purpose of this study was to evaluate the nutritional value and acceptability of cereal bars enriched with dietary fiber and omega-3. 


\section{MATERIAL AND METHODS}

Materials

The brown linseeds used in the flour preparation were obtained in the market of Viçosa (MG, Brazil).

\section{Methods}

Linseed flour preparation

The seeds were submitted to thermal treatment in air circulation stove (Nova Ética ${ }^{\circledR}$, model $400 / 6 \mathrm{ND}$ ) at $150^{\circ} \mathrm{C}$, for 15 minutes (17). After cooling at room temperature, the linseed was ground in a food processor (ARNOß, Optimix model). The resulting flour was placed in polyethylene bags and stored under refrigeration at $4^{\circ} \mathrm{C}$ for approximately seven days.

\section{Preparation of cereal bars}

Four formulations of cereal bars containing 0\% (F1), 5\% (F2), 10\% (F3) and 20\% (F4) of linseed in the form of whole flour and seed were prepared. The percentages were in relation to total formulation, excluding the water. Soy oil was reduced in function of the lipid concentration of the seed (table 1).

For the agglutination syrup, brown sugar, corn glucose and water were heated under agitation in a Teflon ${ }^{\circledR}$ pan at average temperature of $115^{\circ} \mathrm{C}$, for approximately seven minutes. Next, the remaining ingredients were heated on a low flame for five minutes and homogenized to the agglutination syrup. The content of soy oil added was reduced as a function of the levels of lipids in linseed. The mixture was placed in heat-resistant containers and pressed manually. After cooling at room temperature, the cereal bars were cut in a rectangular shape, with a constant weight of $25 \mathrm{~g}$ and conditioned individually in polyethylene plastic wrap for subsequent analyses.

\section{Proximate analysis}

The analyses of moisture, proteins, lipids and ash were carried out in accordance with the Association of Official Analytical Chemists (AOAC) (18). The soluble and insoluble dietary fibers were determined by the enzymatic-gravimetric method, using complete kit for fiber analysis (Sigmaß) according to methodology recommended by the AOAC (19). The carbohydrate content was obtained by difference and the caloric value of the formulations was determined by the sum of calories supplied by proteins, carbohydrates and lipids, using the conversion factors $4 \mathrm{Kcal} . g-1,4 \mathrm{Kcal} . g-1$ and $9 \mathrm{Kcal} . g-1$, respectively (20).

\section{Sensory analysis}

The acceptability of the four cereal bar formulations was carried out in a supermarket of Viçosa, MG, Brazil. Ninetynine consumers, seventy females and twenty-nine males participated in the study.

Cereal bar samples of $6 \mathrm{~g}$ were identified with random three-digit codes and presented to consumers one at a time, using a randomized block design (21). Consumers evaluated global acceptance of the formulations using a structured 09-point hedonic scale (22).

\section{Statistical analyses}

The chemical composition and acceptance data were analyzed by ANOVA followed by post hoc Tukey test, at 5\% significance level, except the total dietary fiber and soluble and insoluble fractions. The results of the ANOVA were expressed as means \pm standard deviation. The statistical analyses were carried out using the software Statistical Analysis Systems (SAS), version 9.1 (2009) licensed by the Federal University of Viçosa.

\section{RESULTS}

The results of the proximate analysis demonstrated that, regarding moisture, the levels of formulations with linseed were higher than the control $(p<0.007)$. The ash concentration of the cereal bars containing 20\% (F4) of linseed was higher $(p<0.00)$ compared with the control $(F 1)$ and the protein content, with no statistical difference $(p>0.05)$ among the four formulations (table 2).

The cereal bars containing linseed presented a lower concentration of carbohydrates in relation to the control $(p<0.004)$ and a higher lipid concentration $(p<0.001)$ than the others (table 2 ). In addition, the concentration of $\alpha$-linolenic fatty acid $(\omega-3)$ increased by $85 \%$ and the linoleic fatty acid $(\omega-6)$ reduced by $25 \%$ in cereal bars with linseed compared with the control.

Total dietary fiber and the soluble and insoluble fractions increased as the amount of added linseed was higher and the caloric value was similar among the cereal bars.

\section{TABLE 1}

Cereal bar formulations $\left(\mathrm{g} \cdot 100 \mathrm{~g}^{-1}\right)$.

Ingredients

Linseed flour

Linseed

Oat

Soy oil

Corn glucose

Brown sugar

Cashew nut

Dried banana

Water

$\begin{array}{ll}- & 2.5 \\ - & 2.5\end{array}$

$\begin{array}{ll}- & 2.5 \\ - & 48\end{array}$

56

3.0

15

12

5.0

10

30
Formulations

F2

2.5

48

2.0

16

13

5.0

11

33
F3

5.0

5.0

44

1.0

16

13

5.0

11

33
F4

10

10

34

-

16

14

5.0

11

33

F1, 0\% linseed cereal bar; F2, 5\% linseed cereal bar; F3, 10\% linseed cereal bar; F4, 20\% linseed cereal bar. 
Results obtained in the sensory analysis are presented in table 4. The cereal bars showed scores superior to 6 in the hedonic scale, among the hedonic terms "like moderately" and "like very much". The formulation without linseed was the least accepted, differing from the others significantly $(p<0.016)$.

\section{DISCUSSION}

The moisture of the cereal with linseed increased in relation to control, probably due to the content of water in the seed, which is higher than oat (10).

As well as in this work, Hussain et al. (23) also observed an increase in the ash content in cookies prepared with linseed flour and attributed it to the minerals present in the seed.

Although the contents of protein did not differ, the values obtained in this study were superior to the products found in the market and in the research of others $(24,25)$. Furthermore, the profile of linseed amino acids characterizes it as less lipidemic and atherogenic than soy or canola proteins (9), cereal bars with linseed are adequate for a healthy diet.

The levels of carbohydrate were reduce in the bars with linseed and inferior to the values found by Brito et al. (24), Freitas and Moretti $(25)$ and in commercial bars $(24,25)$.

Inferior values in the lipid content in cereal bars were observed by Freitas et al. (25) and Silva et al. (26). However, it is necessary to consider the linseed lipid profile, which presents a favorable balance of polyunsaturated, monounsaturated and saturated fatty acids $(7,10)$.

Philippi (11) classifies food according to the content of a nutrient in the portion established by legislation regarding the Dietary Reference Intake (DRI) (27). Foods containing more than 5\% DRI value are considered as source; those containing between 10 and $20 \%$ are considered a good source and those containing over $20 \%$ are an excellent source. Hence, considering the DRI recommendations for men and women from 19 to 50 years, the formulations containing linseed were classified as excellent sources of $\omega-3$ and good sources of $\omega-6$ in a $25 \mathrm{~g}$ portion (table 3 ). Since the appropriate $\omega-3$ and $\omega-6$ intake is associated with the adaptation of the plasmatic lipid profile for the control of the circulative and immune systems, brain functions, among others (28), the inclusion in diet or consumption of linseed bars with high $\omega-3$ concentration contributes to reduce the elevated $\omega-6 / \omega-3$ ratio, characteristic of the Western diet (29).

The increase of dietary fiber in the formulations add of linseed was due to the higher concentration of this nutrient in the linseed than the oat, with a level of around three times

\section{TABLE 2}

Chemical composition of cereal bars $\left(\mathrm{g} \cdot 100^{-1} \mathrm{~g}\right)$.

\begin{tabular}{|c|c|c|c|c|c|}
\hline \multirow[t]{2}{*}{ Nutrients } & \multicolumn{4}{|c|}{ Formulations } & \multirow[b]{2}{*}{$\mathrm{p}$} \\
\hline & $\mathrm{F} 1$ & F2 & F3 & $\mathrm{F} 4$ & \\
\hline Moisture & $9.9^{b} \pm 1.2$ & $14.7^{a} \pm 1.1$ & $13.2^{a} \pm 1.6$ & $11.6^{\mathrm{ab}} \pm 0.93$ & $p<0.007$ \\
\hline Ash & $1.9^{c} \pm 0.04$ & $2.0^{b c} \pm 0.07$ & $2.1^{b} \pm 0.01$ & $2.4^{\mathrm{a}} \pm 0.04$ & $\mathrm{p}<0.00$ \\
\hline Protein & $11.4^{a} \pm 0.47$ & $11.7^{a} \pm 0.30$ & $12.2^{a} \pm 0.59$ & $12.7^{a} \pm 0.45$ & $p>0.05$ \\
\hline Carbohydrate & $65.1^{\mathrm{a}} \pm 1.1$ & $59.7^{\mathrm{b}} \pm 1.1$ & $60.6^{\mathrm{b}} \pm 1.0$ & $57.9^{b} \pm 2.1$ & $p<0.004$ \\
\hline Lipids & $11.3^{b} \pm 0.37$ & $11.9^{b} \pm 0.88$ & $11.9^{b} \pm 0.93$ & $15.5^{\mathrm{a}} \pm 0.69$ & $p<0.001$ \\
\hline Linoleic fatty acid & 3.9 & 3.4 & 2.8 & 2.6 & \\
\hline a-linolenic fatty acid & 0.30 & 1.3 & 2.1 & 4.4 & \\
\hline Total dietary fiber & 4.7 & 6.8 & 8.4 & 12.8 & \\
\hline Soluble dietary fiber & 1.8 & 3.1 & 3.1 & 4.9 & \\
\hline Insoluble dietary fiber & 2.9 & 3.7 & 5.3 & 7.9 & \\
\hline Energy (Kcal) & 407.7 & 392.7 & 398.3 & 421.9 & \\
\hline
\end{tabular}

F1, 0\% linseed cereal bar; F2, 5\% linseed cereal bar; F3, 10\% linseed cereal bar; F4, 20\% linseed cereal bar.

${ }^{*} M$ Means followed by same letter within same line do not differ by ANOVA, at $5 \%$ significance level.

\section{TABLE 3}

Characterization of one cereal bar portion (25 g), considering $\alpha$ - linolenic fatty acid and dietary fiber.

\begin{tabular}{|c|c|c|c|c|c|c|}
\hline \multirow{3}{*}{ Formulations } & \multirow{2}{*}{\multicolumn{2}{|c|}{$\begin{array}{l}\text { Linolenic acid } \\
\mathrm{DRI}^{1}=1.3 \mathrm{~g}\end{array}$}} & \multicolumn{4}{|c|}{ Fiber } \\
\hline & & & \multirow{2}{*}{$\begin{array}{c}\text { Classification }{ }^{2} \\
\text { (w3) }\end{array}$} & \multicolumn{2}{|c|}{ RDC $40=30 g$} & \multirow{2}{*}{$\begin{array}{c}\text { Classification }{ }^{2} \\
\text { (Fiber) }\end{array}$} \\
\hline & Content & $\%$ DRI & & Content & $\%$ DRI & \\
\hline F1 & 0.08 & 6.2 & - & 1.2 & 4.0 & - \\
\hline $\mathrm{F} 2$ & 0.33 & 25 & Excellent Source & 1.7 & 5.7 & Source \\
\hline F3 & 0.53 & 41 & Excelent Source & 2.1 & 7.0 & Source \\
\hline F4 & 1.1 & 84 & Excelent Source & 3.3 & 11 & Good Source \\
\hline
\end{tabular}

F1, 0\% linseed cereal bar; F2, 5\% linseed cereal bar; F3, 10\% linseed cereal bar; F4, 20\% linseed cereal bar.

Based on Al; ${ }^{1}$ PHILIPPI (2008) 
more (10). All of the formulations presented higher levels of total fiber than the commercial bars (24) and the bar produce by Brito et al. (24). Additionally, the cereal bars with linseed showed superior results than those of Freitas and Moretti (25). According to Philippi (11), formulations containing 5\% and $10 \%$ of linseed were considered as dietary fiber sources and formulations with $20 \%$ linseed were a good source.

The caloric value of formulations with linseed was 98.2, 99.5 and $105.5 \mathrm{kcal}$ in a portions of $25 \mathrm{~g}$ (table 2), being similar when compared with commercial cereal bars, which presented values between 90 and $117 \mathrm{kcal}$, when considering the same portion $(24,25)$. Thus, the addition of linseed maintained an adequate caloric value and added the claim of healthy to cereal bars.

The results of the sensorial acceptance indicated that formulations containing linseed obtained good acceptance by the consumers. All of the cereal bars presented higher acceptance than the functional bars produced by Freitas and Moretti (25).

\section{CONCLUSION}

Linseed addition to cereal bars increased the concentrations of dietary fiber, minerals and $\omega-3$ of the product. The formulation with $20 \%$ linseed was the most adequate regarding the chemical and sensory characteristics.

Linseed addition in cereal bars is an option to increase the intake of functional foods, contributing to a healthy diet, and may help reduce the occurrence of several non-communicable diseases. However, new studies are necessary to investigate the effects of the intake of these formulations in the human diet.

\section{RESUMO}

Objetivou-se caracterizar barras de cereais enriquecidas com fibra alimentar e ômega-3, utilizando ingredientes funcionais. Foram desenvolvidas formulações, contendo 0\%, 5\%, 10\% e 20\% de linhaça, realizadas análises químicas centesimal, de ácidos $\alpha$-linolênico e linoléico e aceitabilidade. As concentrações de carboidratos das barras de cereais com linhaça foram menores que o controle $(p<0,004)$ e o teor de proteína não diferiu entre as formulações $(p>0,05)$. A barra de cereais contendo $20 \%$ de linhaça apresentou maior teor de lipídio ( $p<0,001)$. As formulações com 5\% e 10\% de linhaça são consideradas fontes de fibra alimentar e a formulação com $20 \%$, boa fonte. Com relação ao $\omega-3$, as formulações contendo linhaça foram classificadas como excelentes fontes. O valor calórico das barras de cereais foi em torno de $100 \mathrm{kcal} /$ porção. As formulações adicionadas de linhaça apresentaram maior aceitabilidade, e a de $20 \%$ de linhaça apresentou melhor formulação em relação às características químicas e sensoriais.
Portanto, a adição de linhaça às barras de cereais é uma boa opção para desenvolver um produto funcional, que pode contribuir para uma dieta saudável e reduzir várias doenças crônicas não-transmissíveis.

Palavras chave. novos produtos alimentícios, linhaça, propriedades funcionais, aceitabilidade.

\section{REFERENCES}

1. Güemes-vera N, Peña-Bautista RJ, Jiménez-Martínez $C$, Dávila-Ortiz $G$ and Calderón-Domínguez G, Effective detoxification and decoloration of Lupinus mutabilis seed derivatives, and effect of these derivatives on bread quality and acceptance. J Sci Food Agric. 2008; 88(3):1135-43.

2. Mourão LHE, Pontes DF, Rodrigues MCP, Brasil IM, Souza Neto MA, Cavalcante MTB. Obtenção de barras de cereais de caju ameixa com alto teor de fibras. Alim Nutr. 2009; 20 (3):427-33

3. Martinchik AN, Baturin AK, Zubtsov VV, Molofeev VIu. Nutritional value and functional properties of flaxseed. Vopr Pitan. 2012; 81(3):4-10.

4. Toure $A_{;}$Xueming X. Flaxseed Lignans: Source, Biosynthesis, Metabolism, Antioxidant Activity, Bio-Active Components, and Health Benefits. Compr Rev Food Sci Food Safety. 2010; 9:261-9.

5. Giacomino S, Peñas $E$, Ferreyra $V$, Pellegrino $N$, Fournier M, Apro N, Olivera Carrión M, Frias J. Extruded Flaxseed Meal Enhances the Nutritional Quality of Cereal-based Products. Plant Foods Hum Nutr. 2013:1-6.

6. Faintuch J, Schmidt VD, Horie LM, Barbeiro HV, Barbeiro $D F$, Soriano $F G$, et al. Propriedades antiinflamatórias da farinha de linhaça em pacientes obesos. Rev Bras Nutr Clin. 2006; 21(4):273-7.

7. Sugasini D, Lokesh BR. Uptake of $\alpha$-linolenic acid and its conversion to long chain omega-3 fatty acids in rats fed microemulsions of linseed oil. AOCS. Lipids. 2012; 47:1155-67.

8. Santos LES, Bortolozo EAFQ. Ingestão de ômega 3: considerações sobre potenciais benefícios no metabolismo lipídico. Publ. UEPG Ciênc Exatas Terra, Ciênc Agr Eng. 2008; 14(2):161-70.

9. Chung MWY, Lei B, Li-Chan ECY. Isolation and structural characterization of the major protein fraction from NorMan flaxseed (Linum usitatissimum L.). Food Chem. 2005; 90:271-9.

10. United States Department Of Agriculture - USDA. National Nutrient Database for Standard Reference. [acesso 2011 jun 18]. Disponível em: [http://www.nal.usda.gov/fnic/ foodcomp/cgi-bin/list_nut_edit.pl].

\section{TABLE 4}

Means of acceptability scores for cereal bar formulations.

Formulations

F1

F2

F3

F4
Acceptability*

$6.9 b \pm 1.6$

$7.3 a \pm 1.3$

$7.5 \mathrm{a} \pm 1.4$

$7.3 a \pm 1.5$

$\mathrm{p}<0.016$

F1, 0\% linseed cereal bar; F2, 5\% linseed cereal bar; F3, 10\% linseed cereal bar; F4, 20\% linseed cereal bar.

*Means followed by same letter do not differ by ANOVA, at 5\% significance level. 
11. Philippi ST. Pirâmide dos alimentos - Fundamentos básicos da Nutrição. Barueri, SP: Manole, p. 25-27. 2008.

12. Papathanasopoulos A, Camilleri M. Dietary Fiber Supplements: Effects in Obesity and Metabolic Syndrome and Relationship to Gastrointestinal Functions. Gastroenterol. 2010; 138 (1):65-72.

13. Anderson JW, Baird P, Davis Jr RH, Ferreri S, Knudtson $M$, Koraym A, Waters $V$, Williams $C L$. Health benefits of dietary fiber. Nutr Rev. 2009;67(4):188-205.

14. Hjartåker $A$, Aagnes $B$, Robsahm TE, Langseth $H$, Bray $F$, Larsen IK. Subsite-Specific Dietary Risk Factors for Colorectal Cancer: A Review of Cohort Studie. J Oncol. 2013; 2013:1-14.

15. Degáspari CE, Blinder EW, Mottin, F. Perfil nutricional do consumidor de barras de cereais. Visão Acadêm. 2008; 9 (1):49-61.

16. Mahanna K, Moslowitz HR, Lee SY. Assessing Consumer Expectations For Food Bars By Conjoint Analysis. J Sens Stud. 2009; 24:851-70.

17. Morais DC, Moraes EA, Dantas MIS, Carraro JCC, Silva CO, Cecon PR, Martino ESD, Ribeiro SMR. Heat Treatment and Thirty-Day Storage Period do not affect the Stability of Omega-3 Fatty Acid in Brown Flaxseed (Linum Usitatissimum) Whole Flour. Food Nutr Sci. 2011; 2:281-6.

18. AOAC - Association of Official Analytical Chemists. Official Methods of Analysis. Maryland: AOAC, v.2, 1997.

19. AOAC - Association of Official Analytical Chemists. Official Methods of Analysis of the AOAC, 16ed. Washington (DC): AOAC, 2002.

20. BRASIL. Ministério da Saúde. Agência Nacional de Vigilância Sanitária - ANVISA. Resolução RDC no 40 de 21 de março de 2001. Regulamento técnico para rotulagem obrigatória de alimentos e bebidas embalados. Diário Oficial [da] República Federativa do Brasil, Poder Executivo, Brasília, DF, 21 mar.; p.4-5. 2001.

21. Dantas MIS, Andrade GF, Piovesan ND, Martino HSD. Farinhas mistas de trigo e de soja agregam valor nutricional e sensorial em pães. Rev Inst Adolfo Lutz. 2009; 68 (2):209-14.

22. Reis RC, Regazzi AJ, Carneiro JCS, Minim VPR. Mapa de preferência. In: Minim, VPR, editores. Análise sensorial: Estudo com consumidores. Viçosa: Ed UFV; p. 13-50. 2006.

23. Hussain S, Anjum FM, Butt MS, Khan MI, Asghar A. Physical and Sensoric Attributes of Flaxseed Flour Supplemented Cookies. Turk J Biol 2006;30:87-92.

24. Brito I P, Campos JM, Souza TFL, Wakiyama C, Azeredo GA. Elaboração e avaliação global de barra de cereais caseira. $B$ Ceppa. 2004; 22(1):35-50.

25. Freitas DGC, Moretti RH. Caracterização e avaliação sensorial de barra de cereais funcional de alto teor protéico e vitamínico. Ciênc Tecnol Alim. 2006; 26(2):318-24.

26. Silva IQ, Oliveira BCF, Lopes AS, Pena RS. Obtenção de barra de cereais adicionada do resíduo industrial de maracujá. Alim Nutr. 2009; 20(2):321-329.

27. IOM. The Dietary Reference Intakes: The essencial guide to nutrient requeriments. Washington, D.C.: Institute of Medicine of the Nacional Academies. 2006.

28. Martin CA, Almeida $V V$, Ruiz MR, Visentainer JEL, Matshushita M, Souza NE, et al. Ácidos graxos poliinsaturados ômega-3 e ômega-6: importância e ocorrência em alimentos. Rev Nutr. 2006; 19(6):761-70.

29. Simopoulos $A$. The importance the omega-6/ omega-3 fatty acid ratio in cardiovascular disease and other chronic disease. Exp Biol Med 2008; 233:674-88. 